\title{
Bromide dilution in adults: optimal equilibration time after oral administration
}

Citation for published version (APA):

van Marken Lichtenbelt, W. D., Kesten, A., Baarends, E. M., \& Westerterp, K. R. (1996). Bromide dilution in adults: optimal equilibration time after oral administration. Journal of Applied Physiology, 81, 653-656. https://doi.org/10.1152/jappl.1996.81.2.653

Document status and date:

Published: 01/01/1996

DOI:

10.1152/jappl.1996.81.2.653

Document Version:

Publisher's PDF, also known as Version of record

Document license:

Taverne

Please check the document version of this publication:

- A submitted manuscript is the version of the article upon submission and before peer-review. There can be important differences between the submitted version and the official published version of record.

People interested in the research are advised to contact the author for the final version of the publication, or visit the DOI to the publisher's website.

- The final author version and the galley proof are versions of the publication after peer review.

- The final published version features the final layout of the paper including the volume, issue and page numbers.

Link to publication

\footnotetext{
General rights rights.

- You may freely distribute the URL identifying the publication in the public portal. please follow below link for the End User Agreement:

www.umlib.nl/taverne-license

Take down policy

If you believe that this document breaches copyright please contact us at:

repository@maastrichtuniversity.nl

providing details and we will investigate your claim.
}

Copyright and moral rights for the publications made accessible in the public portal are retained by the authors and/or other copyright owners and it is a condition of accessing publications that users recognise and abide by the legal requirements associated with these

- Users may download and print one copy of any publication from the public portal for the purpose of private study or research.

- You may not further distribute the material or use it for any profit-making activity or commercial gain

If the publication is distributed under the terms of Article $25 \mathrm{fa}$ of the Dutch Copyright Act, indicated by the "Taverne" license above, 


\title{
Bromide dilution in adults: optimal equilibration time after oral administration
}

\author{
WOUTER D. VAN MARKEN LICHTENBELT, ARNOLD KESTER, \\ ERICA M. BAARENDS, AND KLAAS R. WESTERTERP \\ Department of Human Biology, University of Limburg, 6200 MD Maastricht, The Netherlands
}

\begin{abstract}
Marken Lichtenbelt, Wouter D. van, Arnold Kester, Erica M. Baarends, and Klaas R. Westerterp. Bromide dilution in adults: optimal equilibration time after oral administration. J. Appl. Physiol. 81(2): 653-656, 1996.Extracellular water is often estimated by bromide dilution. The time interval between oral administration of the dose and blood sampling varies considerably among studies. Because at least two processes are involved during equilibration (distribution of the dose and bromide leaving the body), we performed a bromide-dilution experiment and analyzed the decay data by fitting a biexponential curve. The experiment was carried out in 11 healthy adults ( 8 women and 3 men, age 21-39 yr). Bromide ingestion ( $60 \mathrm{mg} \mathrm{Br} / \mathrm{l}$ estimated total body water) was followed by blood sampling at $2,3,4,6,10,25$, and 105 (or 170) $\mathrm{h}$. The bromide concentration in serum ultrafiltrate was determined with high-performance liquid chromatography. The bromide concentration in serum after dose intake showed a significant decrease over time. One-exponent functions significantly fitted the data. The two-exponent functions fitted the data significantly better ( $F$-test, $P<$ 0.0001). A model combining the data from all subjects fitted just as well. Equilibration time can be defined as the time at which the first exponential function, which represents distribution of the dose, has decreased to $5 \%$ of its starting value. According to this model, the equilibration time of orally administered bromide should be $8.5-11.7 \mathrm{~h}$. This can be achieved by an overnight equilibration.
\end{abstract}

extracellular water; high-performance liquid chromatography; multiple-pool model; corrected bromide space

BROMIDE DILUTION ( $\mathrm{NaBr} ;{ }^{28} \mathrm{Br}$ ) is a widely used method to estimate the extracellular water (ECW) compartment (plasma water, interstitial water including lymph, and connective tissue water including bone and cartilage). Determination of ECW is important in clinical practice. Changes in ECW volume have been reported in many diseases [malnutrition (13) and heart disease] and during dialysis. Moreover, combined with the measurement of total body water (TBW), the intercellular water can be determined, which, in turn, can be used as a measurement for the body cell mass. Finally, the method of bromide dilution is regularly used in validation studies of other techniques for body composition assessment, such as bioelectrical impedance.

The tracer can be given intravenously (15) or orally. In many clinical studies, the oral route is preferred. The time of the blood sampling after oral administration of the dose varies considerably. Sometimes a 2 -h equilibration time is used (1); more often, $4-6 \mathrm{~h}$ is used $(8,9,10,12)$, whereas other studies use $10 \mathrm{~h}(5)$ and some even use $18 \mathrm{~h}(6)$.

Validation studies on equilibration times in humans are scarce, and the results are conflicting. According to these studies, an equilibration time of bromide ranges from 6 (11) to $24 \mathrm{~h}$ (3). Other studies show that there is no significant difference among 2,3 , and $4 \mathrm{~h}$ of equilibration (15) or the bromide concentration $([\mathrm{Br}])$ remains constant (within $2.5 \%$ ) from 2 to $7 \mathrm{~h}$ after the administration of bromide (4).

Most studies investigate differences in bromide space at fixed time intervals after dose administration within individuals for a given protocol. These experiments, however, cannot provide information about the equilibration process. We therefore performed a bromidedilution experiment by obtaining multiple samples over time after oral administration of $\mathrm{NaBr}$ and analyzed the decay data by fitting a biexponential curve.

\section{METHODS}

Subjects. Eight adult women, age 21-26 yr, and three adult men, age 27-39 yr, volunteered to participate in the study, which was approved by the Medical Ethical Committee of the University of Limburg, Maastricht, The Netherlands. They were in good health and were not selected by any criteria relating to their body composition.

Experimental design. After an overnight fast, a background blood sample was taken at 0830 , followed by the intake of $\mathrm{NaBr}$. A weighed amount of $\mathrm{NaBr}(60 \mathrm{mg} \mathrm{Br} / \mathrm{l}$ estimated TBW; Pharmacopea European Genfarma, Maarssen, The Netherlands) was diluted with tap water to 0.05 liter for intake. Bromide ingestion was followed by blood sampling at 2, 3, 4, $6,10,25$, and $105 \mathrm{~h}$ in four subjects (experiment series 1 ) and at $2,3,4,6,10,25$, and $170 \mathrm{~h}$ in seven subjects (experiment series 2 ). Food intake was not allowed until $6 \mathrm{~h}$ after dose administration.

Laboratory analyses. $[\mathrm{Br}]$ in serum ultrafiltrate was determined with high-performance liquid chromatography according to the anion-exchange chromatographic method described by Miller et al. (10). We used a flow rate of $1.0 \mathrm{ml} / \mathrm{min}$. The pressure was $45 \mathrm{bar}$, and the amount injected was $115 \mathrm{ml}$. The retention times for chlorine and bromine were 10.0 and 11.3 min, respectively, and the peaks were clearly separated. The [Br] was determined by the area under the curve as calibrated with bromine standards. The between-run coefficient of variation was $0.97 \%(n=10)$.

Corrected bromide space (CBS) was calculated according to the formula $(2,10)$

$$
\text { CBS (liters) }=\frac{\mathrm{Br} \text { dose }(\mathrm{mmol})}{\left[\mathrm{Br}_{\mathrm{f}}\right]-\left[\mathrm{Br}_{\mathrm{b}}\right](\mathrm{mmol} / \mathrm{l})} \times 0.90 \times 0.95
$$

where $\left[\mathrm{Br}_{b}\right]$ is the background $[\mathrm{Br}]$ in serum ultrafiltrate, $\left[\mathrm{Br}_{\mathrm{f}}\right]$ is the final $[\mathrm{Br}]$ in serum ultrafiltrate, 0.90 is the correction factor for the distribution of bromide in the nonextracellular sites, and 0.95 is the correction factor for the Donnan equilibrium. When bromide is determined in serum, an additional correction factor is applied for the concentration of water in serum. Because we measured the $[\mathrm{Br}]$ in serum ultrafiltrate, in which the water concentration approaches $100 \%$, this correction was not needed in our calculations (10). 
Table 1. Subject characteristics and corrected bromide space at intervals after an oral dose of $\mathrm{NaBr}$

\begin{tabular}{|c|c|c|c|c|c|c|c|c|c|c|c|c|}
\hline \multirow{2}{*}{$\begin{array}{c}\text { Subject } \\
\text { No. }\end{array}$} & \multirow[b]{2}{*}{ Sex } & \multirow{2}{*}{$\begin{array}{l}\text { Age, } \\
\text { yr }\end{array}$} & \multirow{2}{*}{$\begin{array}{l}\text { Height, } \\
\text { cm }\end{array}$} & \multirow{2}{*}{$\begin{array}{l}\text { Weight, } \\
\text { kg }\end{array}$} & \multicolumn{8}{|c|}{ Corrected Bromide Space, liters } \\
\hline & & & & & $2 \mathrm{~h}$ & $3 \mathrm{~h}$ & $4 \mathrm{~h}$ & $6 \mathrm{~h}$ & $10 \mathrm{~h}$ & $25 \mathrm{~h}$ & $105 \mathrm{~h}$ & $170 \mathrm{~h}$ \\
\hline 1 & $\mathrm{~F}$ & 23 & 170 & 51 & 14.0 & 13.5 & 14.4 & 14.7 & 15.4 & 15.7 & 20.9 & \\
\hline 2 & $\mathrm{~F}$ & 23 & 173 & 61 & 13.2 & 13.4 & 14.2 & 15.0 & 15.1 & 15.5 & 18.7 & \\
\hline 3 & M & 34 & 180 & 66 & 15.6 & & 16.1 & 16.3 & 16.8 & 17.5 & 21.2 & \\
\hline 4 & M & 39 & 184 & 70 & 16.0 & 16.2 & 16.7 & 17.3 & 17.6 & 17.9 & 23.4 & \\
\hline 5 & $\mathrm{~F}$ & 26 & 164 & 62 & 12.5 & 12.9 & 13.2 & 14.6 & 14.1 & 14.7 & & 22.8 \\
\hline 6 & $\mathrm{~F}$ & 21 & 172 & 52 & 12.5 & 12.9 & 13.1 & 13.6 & 14.1 & 15.2 & & 21.3 \\
\hline 7 & $\mathrm{~F}$ & 21 & 170 & 80 & 14.7 & 14.7 & 15.0 & 14.3 & 15.6 & 17.4 & & 26.3 \\
\hline 8 & M & 26 & 200 & 82 & 19.6 & 19.5 & 19.4 & 20.9 & 21.0 & 23.4 & & 33.8 \\
\hline 9 & $\mathrm{~F}$ & 25 & 170 & 54 & 12.1 & 12.4 & & 13.5 & 13.6 & 14.2 & & 20.0 \\
\hline 10 & $\mathrm{~F}$ & 22 & 168 & 56 & 11.9 & 13.0 & 13.4 & 13.8 & 14.6 & 15.2 & & 19.8 \\
\hline 11 & $\mathrm{~F}$ & 22 & 169 & 55 & 11.9 & 12.5 & 12.8 & 13.1 & 13.7 & 13.9 & & 19.7 \\
\hline Mean & & 25.6 & 174.5 & 62.6 & & & & & & & & \\
\hline
\end{tabular}

F, female; M, male.

Data analyses. The ECW in the body is distributed among several anatomic compartments. After oral administration, there is a finite delay from the time when the bromide is administered until it is completely distributed over each of these compartments. In the meantime, bromide is excreted in the urine as well. We tested whether the bipool models fitted the data better than the single pool using an $F$-test. In a single pool, the tracer enrichment $(\mathrm{E})$ at any time $(t)$ for one subject can be described as follows

$$
\mathrm{E}_{\iota}=\mathrm{E}_{0} e^{-t / b}
$$

where $\mathrm{E}_{0}$ is the enrichment at $t=0$ and $b$ is a time constant.

In a bicompartment pool the tracer $\mathrm{E}$ at $t$ is

$$
\mathrm{E}_{t}=\mathrm{E}_{1} e^{-t / b_{1}}+\mathrm{E}_{2} e^{-t / b_{2}}
$$

A model was developed to include the data of all subjects if identical shapes of the curves of decay and subject-dependent start enrichments were assumed. Therefore, in the model, $b_{1}$, $b_{2}$, and $\mathrm{E}_{2} / \mathrm{E}_{1}=r$ were equal for each subject $(n)$, resulting in the following formula

$$
\mathrm{E}_{t}=r \mathrm{E}_{n} e^{-t / b_{1}}+\mathrm{E}_{n} e^{-t / b_{2}}
$$

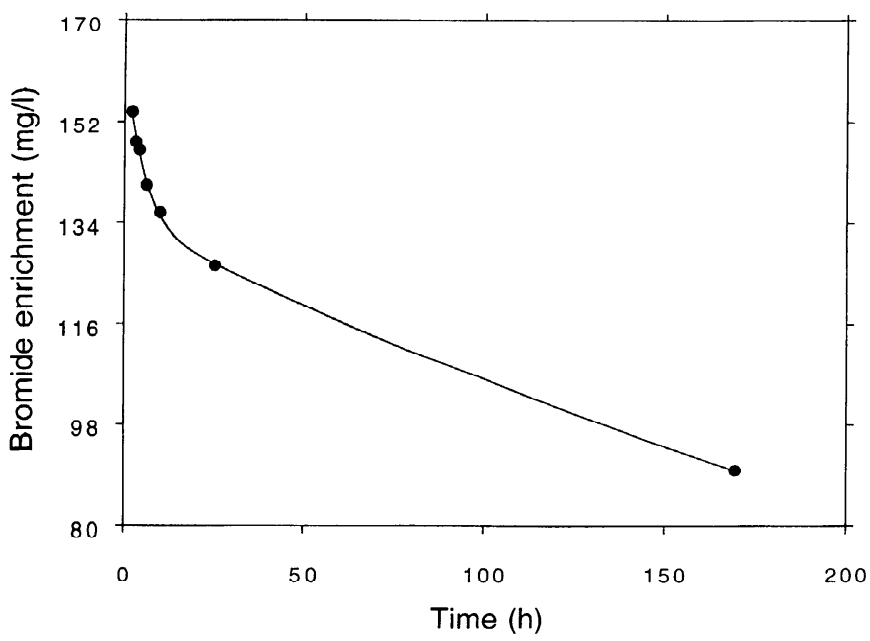

Fig. 1. Example of time course for equilibration of bromide after oral administration. Calculated 2-exponent regression line of subject 8 is plotted: $y=134 e^{-\mathrm{x} / 426}+29.6 e^{-\mathrm{x} / 5.16} ; R=0.999 ; P<0.001$. or

$$
\mathrm{E}_{t}=\mathrm{E}_{n}\left(r e^{t / b_{1}}+e^{-t / b_{2}}\right)
$$

The parameters $\mathrm{E}_{1}, \ldots, \mathrm{E}_{11}, b_{1}, b_{2}$, and $r$ were estimated simultaneously. All curve fitting was performed with nonlinear least squares regression (14).

\section{RESULTS}

[Br] in serum after dose intake showed a decrease from 2 to $170 \mathrm{~h}$. This decrease resulted in an increase in the calculated CBS over time (Table 1). The mean decrease of [Br] in serum was relatively large from 2 to $\sim 10 \mathrm{~h}$ and leveled off after $10 \mathrm{~h}$ (Fig. 1). The oneexponent functions significantly fitted the data for each subject. The two-exponent functions fitted the data significantly better $\left(F_{22,31}=7.732 ; P<0.0001\right.$; Table 2$)$.

The decay of the bromide enrichment using the data from all subjects and the model (see METHODS) showed comparable results (Table 2 ). The one-exponent function significantly fitted the data $(R=0.935)$. The two-exponent function fitted the data significantly bet-

Table 2. $R$ values of fit of data on bromide enrichment in serum at different time intervals after bromide intake by mono- and biexponential functions

\begin{tabular}{ccc}
\hline & \multicolumn{2}{c}{$R$ Values of Function } \\
\cline { 2 - 3 } Subject No. & 1 Exponent & 2 Exponent \\
\hline 1 & 0.927 & 0.968 \\
2 & 0.810 & 0.983 \\
3 & 0.962 & 0.998 \\
4 & 0.954 & 0.991 \\
5 & 0.919 & 0.981 \\
6 & 0.920 & 0.999 \\
7 & 0.949 & 0.983 \\
8 & 0.938 & 0.990 \\
9 & 0.917 & 0.994 \\
10 & 0.792 & 0.995 \\
11 & 0.919 & 0.997 \\
$1-11$ (model) & 0.935 & 0.982 \\
\hline
\end{tabular}


$\operatorname{ter}\left(F_{2,60}=76.20 ; P<0.0001\right)$

$$
\left[\mathrm{Br}^{+}\right]=\mathrm{E}_{n}\left(0.237 e^{-t / 2.85}+e^{-t / 392.9}\right)
$$

where $t$ is time in hours $(R=0.982)$ (Fig. 2).

The $95 \%$ confidence limits for the first exponential parameter were 1.81-3.89. In this model, one significant outlier was excluded (subject 7 at $4 \mathrm{~h}$ : Bonferroni corrected outlier test, $F_{1,60}=14.72 ; P<0.05$ ). The first exponent describes the rate of distribution, and the second describes the rate of loss of the bromide from the body. The equilibration time can be defined as the time at which the first exponential function has decreased to $5 \%$ of its starting value. According to this model, the equilibration time of orally administered bromide should be $8.5 \mathrm{~h}$, taking the upper $95 \%$ confidence limit at $11.7 \mathrm{~h}$. From the second exponent, the average theoretical initial enrichment can be calculated by backextrapolation. On average, this amounts to $126.3 \mathrm{mg} / \mathrm{l}$. By using the biexponential formula, the enrichment relative to the back-extrapolated enrichment can be plotted against sampling time (Fig. 3). These calculations reveal that the deviation from theoretical initial enrichments were $4.9 \%$ at $4 \mathrm{~h}, 2.1 \%$ at $6 \mathrm{~h},-0.2 \%$ at 8 $\mathrm{h}$, and $-1.5 \%$ at $10 \mathrm{~h}$.

\section{DISCUSSION}

We studied the decay of bromide dilution after an oral dose of $\mathrm{NaBr}$. Contrary to previous validation studies, this study showed that there was a significant, and physiologically important, reduction in the $[\mathrm{Br}]$ even $4 \mathrm{~h}$ after dose administration, which could mainly be attributed to the process of the distribution of bromide in the body. Simple statistics used in previous studies can give the wrong impression that there is no significant difference between $[\mathrm{Br}]$ values at different sampling times. To show this, we also performed an analysis of variance test. The results from Scheffés $F$-test show that the $[\mathrm{Br}]$ between 2 and 3,2 and 4, 3 and 4, 4 and 6,6 and 10 , and finally 10 and $25 \mathrm{~h}$ were not statistically significantly different. From our data, it is evident that this does not mean that individual plasma $[\mathrm{Br}]$ values do not drop significantly.

Biexponential curve fitting could explain, on average, $>98 \%$ of the observed variation in $[\mathrm{Br}]$ over time and fitted significantly better than a single-exponent fit. From the curve-fitting data, it could be derived that in 8.5-11.7 $\mathrm{h}$ the first exponent, representing the rate of distribution, was down to $5 \%$ of its starting value, and thus the distribution phase was complete. Clearly, some bromide was lost in the urine by that time. However, calculations showed that the $[\mathrm{Br}]$ values at sampling times between 8.5 and $11.7 \mathrm{~h}$ were close (within 2.5\%) to the back-extrapolated initial values. The results of this study imply that sampling at $6 \mathrm{~h}$ or less after bromide administration means that the bromide is not yet completely mixed with the body water compartment. This may first of all underestimate the CBS. More importantly, because of the steepness of the first part of the slope (Fig. 2), even within one study

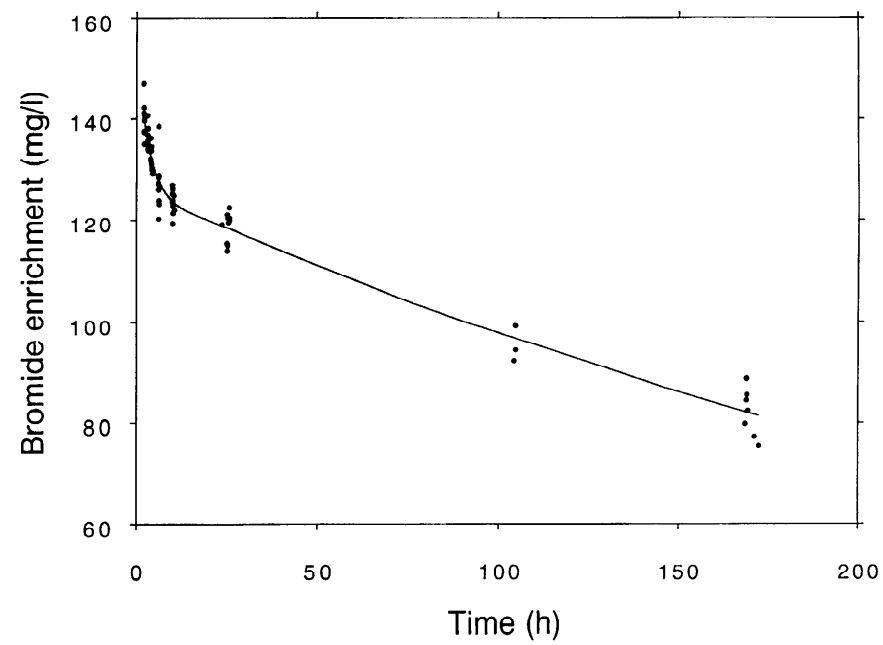

Fig. 2. Average time course for equilibration of bromide after oral administration. Calculated 2-exponent regression line using data from 11 subjects and biexponential model is plotted: bromide concentration $=126.3\left(0.237 e^{-\mathrm{t} / 2.85}+e^{-\mathrm{t} / 392.9}\right)(R=0.982 ; P<0.001)$ where $t$ is timc in hours and 126.3 is average value of the initial enrichment. Plotted data have been adjusted to same initial enrichment.

small differences in sampling time or the behavior (activity) of the subjects may result in large differences in the resulting CBS. Finally, we show, with deuterium dilution, that body size may affect the time of equilibration (7). The larger the body, the larger the error in TBW estimation, when (too) short equilibration times are used. It is likely that such errors also occur in ECW determination using bromide equilibration times of $6 \mathrm{~h}$ or shorter. The decision on which sampling time to choose will, apart from the above-mentioned arguments, in many cases depend on the accuracy of the other measurements taken (e.g., TBW by dilution).

The results from this study thus show that for comparison among and within studies, the optimal equilibration time is between 8.5 and $11.7 \mathrm{~h}$. This is much longer than what many studies have used so far. In most studies, including those in a clinical setting, an

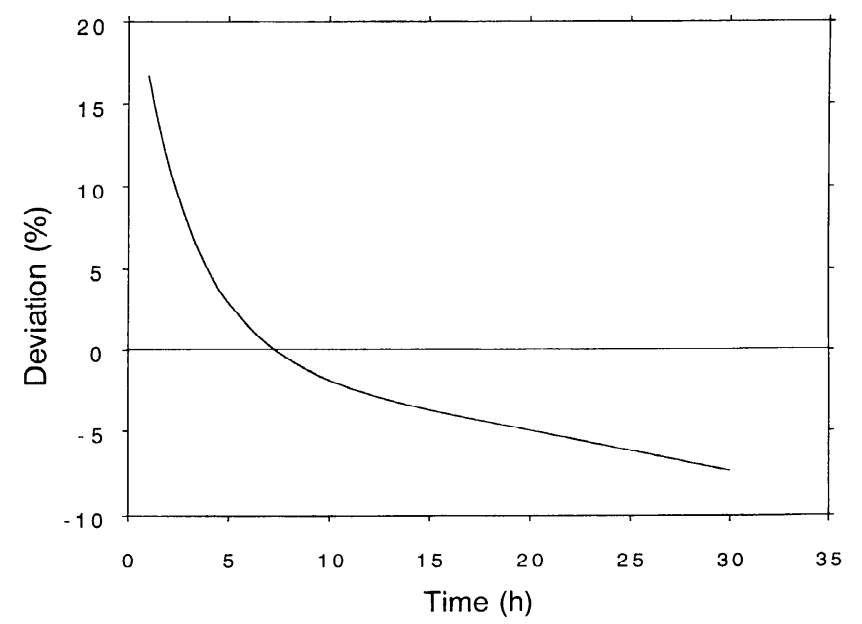

Fig. 3. Deviation in plasma bromide enrichment relative to extrapolated initial enrichment in relation to sampling time. 
8.5- to 11.7-h equilibration time can be readily attained by using an overnight equilibration protocol.

We thank Mikael Fogelholm for assistance during the experiments.

Address for reprint requests: W. D. van Marken Lichtenbelt, Dept. of Human Biology, Univ. of Limburg, PO Box 616, 6200 MD Maastricht, The Netherlands.

Received 16 June 1995; accepted in final form 11 March 1996.

\section{REFERENCES}

1. Baumgartner, R. N., P. M. Stauber, D. McHugh, S. Wayne, P. J. Garry, and S. B. Heymsfield. Body composition in the elderly using multicompartmental methods. Basic Life Sci. 60: 251-254, 1993.

2. Bell, E. F., E. E. Ziegler, and G. B. Forbes. Letter to the editor. Pedriatr. Res. 18: 392-393, 1984.

3. Bradley, J. E. S., D. Davidsson, I. MacIntyre, and A. Rapoport. Estimation of extracellular fluid volume using ${ }^{82} \mathrm{Br}$. Biochem. J. 62: 33P-34P, 1956.

4. Cheek, D. B. Estimation of the bromide space with a modification of Conway's method. J. Appl. Physiol. 5: 639-645, 1953.

5. Deurenberg, P., and F. J. Schouten. Loss of total body water and extracellular water assessed by multifrequency impedance. Eur. J. Clin. Nutr. 46: 247-255, 1992.

6. Hannan, W. J., S. J. Cowen, K. C. Fearon, C. E. Plester, J. S. Falconer, and R. A. Richardson. Evaluation of multifrequency bio-impedance analysis for the assessment of extracellular and total body water in surgical patients. Clin. Sci. 86: 479-485, 1994.
7. Van Marken Lichtenbelt, W. D., K. R. Westerterp, and L. Wouters. Deuterium dilution as a method for determining total body water: effect of test protocol and sampling time. $B r . J$. Nutr. 72: 491-497, 1994.

8. Van Marken Lichtenbelt, W. D., K. R. Westerterp, L. Wouters, and S. C. M. Luijendijk. Validation of bioelectricalimpedance measurements as a method to estimate body-water compartments. Am. J. Clin. Nutr. 60: 159-166, 1994.

9. Miller, M. E., and C. J. Cappon. Anion-exchage chromatographic determination of bromide in serum. Clin. Chem. 30: 781-783, 1984.

10. Miller, M. E., J. M. Cosgriff, and G. B. Forbes. Bromide space determination using anion-exchange chromatography for measurement of bromide. Am. J. Clin. Nutr. 50: 168-171, 1989.

11. Nicholson, J. P., and Z. F. Zila. A 6 hour method for determining the extracellular fluid volume in human subjects. Clin. Chim. Acta 2: 340-344, 1957.

12. Scheltinga, M. R., J. O. Jacobs, T. D. Kimbrough, and D. W. Wilmore. Alterations in body fluid content can be detected by bioelectrical impedance analysis. J. Surg. Res. 50: 461-468, 1991.

13. Shizgal, H. M. The effect of malnutrition on body composition. Surg. Gynecol. Obstet. 152: 22-26, 1981.

14. Systat. SYSTAT for Windows: Statistics, Version 5. Evanston, IL: Systat, 1992.

15. Vaisman, N., P. B. Pencharz, G. Koren, and J. K. Johnson. Comparison of oral and intravenous administration of sodium bromide for extracellular water measurements. Am. J. Clin. Nutr. 46: 1-4, 1987. 